\title{
Study of Latent Matrix Metalloproteinase- 1 Activity in Serum and Synovial Fluid of Patients with Rheumatoid Arthritis
}

\author{
Zahraa M. Hamoudatt Layla A. Mustafa \\ Department of Chemistry \\ College of Science \\ University of Mosul
}

\author{
Saad M.AL-Hasani* \\ Rheumatology Section \\ Ibin Sina Teaching Hospital \\ * Clinical supervisor
}

(Received 21/10/2012 ; Accepted 8/4/2013 )

\begin{abstract}
This research was concerned with the measurement of latent matrix metalloproteinase-1 (MMP-1) activity in serum and synovial fluid (SF) of rheumatoid arthritis patients, and evaluation the effect of some factors like gender, age, geographical place and smoking on the enzyme activity.

The study included (158) patients (132 female, 26 male) aged from (19-83) year, attending the rheumatology clinic at Ibn Sina teaching hospital in Nineveh Governorate.

Sixty healthy volunteers of matched age and gender were utilized as control.

The results showed that the activity of enzyme was significantly different between the SF and the serum of patients with RA $(586.85 \pm 40.89 \mathrm{ng} / \mathrm{ml}$, vs. $249.45 \pm 61.11 \mathrm{ng} / \mathrm{ml} ; \mathrm{P}<$ $0001)$ respectively, and between serum of RA patients and serum of control (249.45 \pm 61.11 $\mathrm{ng} / \mathrm{ml}$, vs. $125.46 \pm 54.88 ; \mathrm{P}<001$ ) respectively.

The results indicated that the number of rheumatoid arthritis females were more than males by (5) times and it is most common after the age between $40^{\text {th }}$ and $50^{\text {th }}$ years. Moreover, the results showed that the number of patients who live in urban places is higher than that in rural places.

The study, also, showed that the enzyme activity was significantly increased among smoker patients.

Finally the results showed that there was no significant effect of age, gender and geographic place on the enzyme activity.
\end{abstract}

Keywords: Matrix metalloproteinase-1, Rheumatoid arthritis.

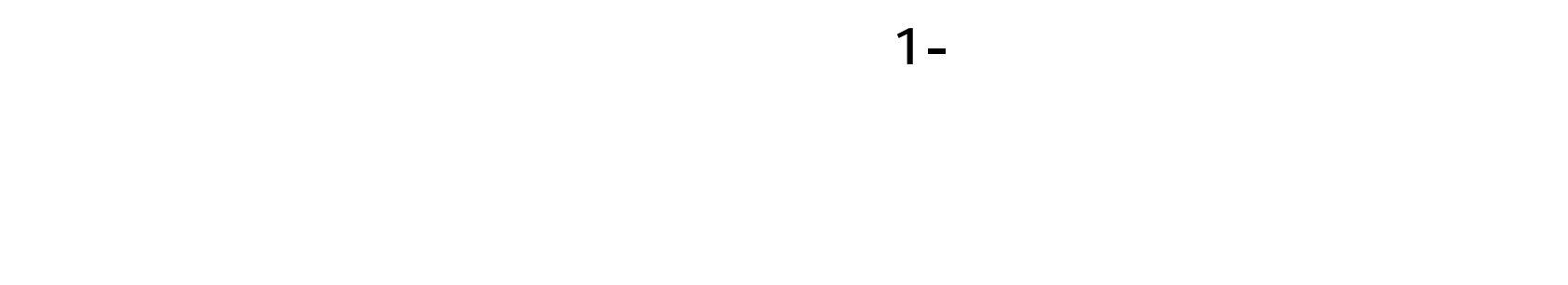

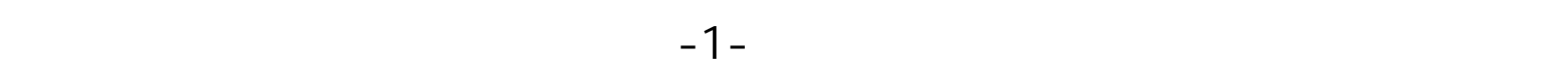

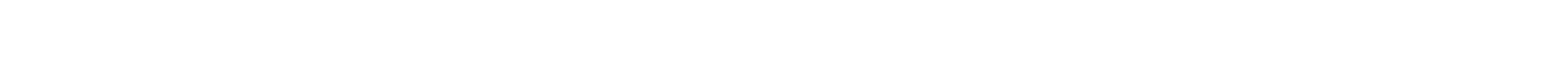

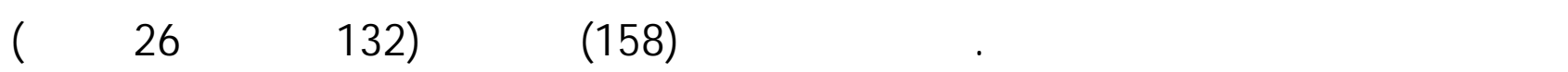


تراومت أعمارهم بين (19 -83)سنة، مم ن يرلجع -ون عي الة المفاص لـ ف مي مست شفى الب ننس يـا

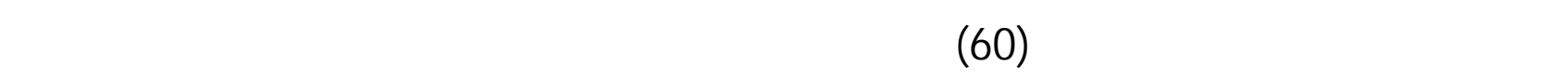

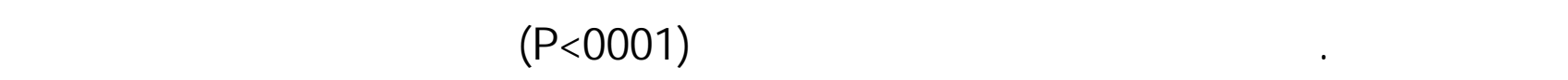

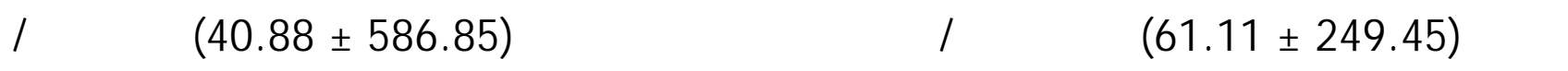

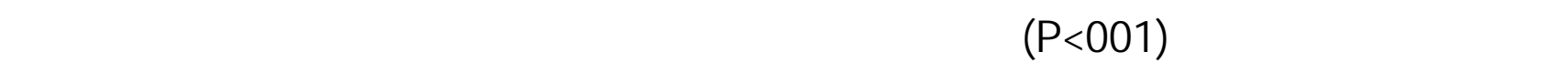

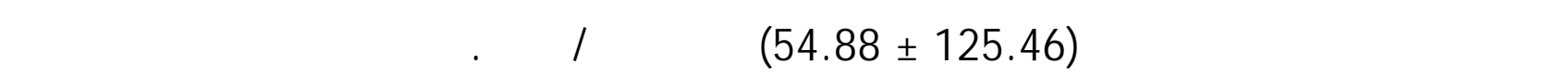

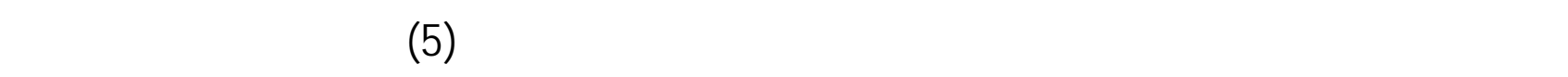

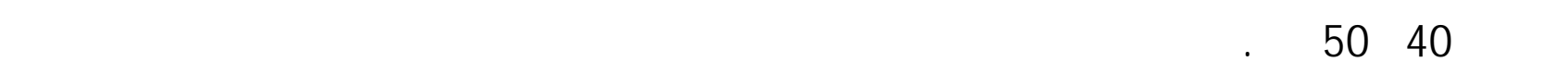

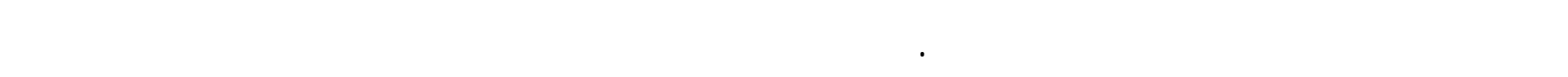

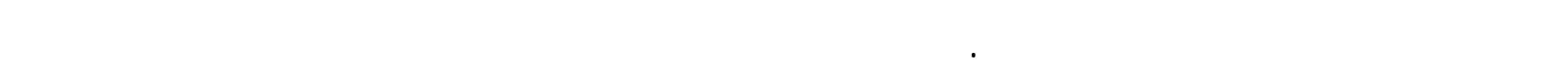
والمقع الجغرافي على فعالية الأنزيم.

\section{الكاملت الدالة: الفزيم الميتالو بروتينيز -1، التهلب المفاصل الرثوي.}

\section{INTRODUCTION}

Rheumatoid arthritis (RA) is a chronic systemic disease, in which various joints in the body are inflamed, leading to swelling, pain, stiffness and a possible loss of function. It is an autoimmune disease in which the body's immune system attacks itself (Schere et al., 2010). RA might affect many tissues and organs such as, lung, pericardium, pleura and sclera, also nodular lesions, most common in subcutaneous tissue, but principally attack synovial joints (John et al., 2008). The etiologies of RA are incompletely understood (Schere et al., 2010). About $1 \%$ of the world's population is afflicted by RA, and women are three times more often than men (Freimanis et al., 2010). Onset is most frequent at the age of $40^{\text {th }}$ to $50^{\text {th }}$, but people of any age can be affected (Mohan and Priyav, 2010). The destruction of cartilage and bone in RA is mediated by abnormal release of proteolysis enzymes such as the matrix metalloproteinases (MMPs) in rheumatoid synovium, which stimulated by persistent inflammation (Schere et al., 2010; Chen et al., 2012). These collagens were considered to be crucial to the progression of destructive arthritis due to their ability to cleave native type II collagen (Peak et al., 2005).

Interstitial collagenase, also named matrix metalloproteinase-1 (E. C. 3. 4. 24.7; MMP-1) is a member of the MMP gene family that cleave the collagen triple helix to yield characterized $25 \%$ and $75 \%$ of the original molecule (Maeda et al., 1995; Kaar et al., 2008; Alizadeh et al., 2008; Daboor et al., 2012).

Matrix metalloproteinase-1 was described by Jerome Gross and Charles Lapier in 1962 (Gross and Nagai, 1965). They observed enzymatic activity on collagen triple helix degradation, during metamorphosis of tadpole tail by placing a tadpole in collagen matrix plate (Alizadeh et al., 2008; Biljana et al., 2011). 
This study aimed to determine the activity of enzyme latent-MMP-1 in serum and synovial fluid (SF) of patients with RA.

\section{MATERIALS AND METHODS}

The study included (158) patients with RA, under treatment (132 Female, 26 Male) aged between (19-83) years, as outpatients attending the rheumatology clinic at Ibn- Siena teaching hospital. These patients were fulfilled the American College Rheumatology (ACR) criteria for diagnosis of RA. All of them were taking non-steroidal- anti- inflammatory drug (NSAIDs) and disease modifying anti- rheumatic drugs (DMARDs) with or without combination. Moreover, they haven't afflicted by other diseases.

The study included (60) healthy volunteers as control (36 Female, 24 Male), their aged between (23-78) years. Both patients and control groups were divided into categories aged $(39 \leq, 40-55$ and $61 \geq)$ years.

Venous blood serum was separated by centrifugation at $3000 \mathrm{xg}$ for (10) minutes and then divided in aliquots. Each serum's subject was frozen at $\left(-20^{\circ} \mathrm{C}\right)$ until examination (Matsumoto et al., 2006).

Synovial fluid (SF) samples were obtained from the patients by collecting (10) $\mathrm{ml}$ from knee joint, then transferred immediately to clean dry tube and centrifuged at $3000 \mathrm{xg}$ for (20) minutes to remove cellular debris. The supernatant was stored at $\left(-20^{\circ} \mathrm{C}\right)$ until examination (Peak et al., 2005).

\section{Determination of Latent- Matrix Metalloproteinase-1 (MMP-1).}

Metalloproteinase -1 (MMP-1) activity in form latent-MMP-1 (inactive or pro enzyme) were assayed using a specific double antibody sandwich Enzyme Linked Immunosorbant Assay (ELISA) (Peak et al., 2005; Kim et al., 2011) for 125 samples, which included blood samples for control and patients.

The activity of enzyme was assayed using a commercial Human- MUMP-1 ELISA kit, kindly donated by Ray Bio United Kingdom. This kit has a limit of detection of $8 \mathrm{pg} / \mathrm{ml}$ and performed according to the manufacture instruction. All sample serum and SF were diluted with buffer's diluent 1:20 and 1:40 respectively.

\section{Statistical Analysis}

All values were expressed as mean \pm SD by T-test and Duncan- ANOVA, P value less than $(0.05)$ were considered statistically significant. All statistical analysis was performed using SPSS, version 20 (Kirkwood, 1988).

\section{RESULTS AND DISCUSSION}

The reference value of latent-MMP-1 activity obtained from this study was in the range of (47.38- 227.72) $\mathrm{ng} / \mathrm{ml}$.

The results in Fig. (1) and Table (1) showed that the activity of the enzyme was significantly different between the SF and serum of patients with RA $(586.85 \pm 40.89 \mathrm{ng} /$ $\mathrm{ml}$, vs. $249.45 \pm 61.11 \mathrm{ng} / \mathrm{ml} ; \mathrm{P}<0001)$ respectively, and between serum of patient with RA and serum of control $(249.45 \pm 61.11 \mathrm{ng} / \mathrm{ml}$, vs. $125.46 \pm 54.88 \mathrm{ng} / \mathrm{ml} ; \mathrm{P}<001)$ respectively. These results were accordance with the results of other investigations (Peak et al., 2005; Kim et al., 2011). 
This result is probably due to the presence of proinflammatory cytokines, particularly IL-1, IL-6 and TNF-alpha (Brennan and Mclnnes, 2008; Seven et al., 2009; Kokebie et al., 2011; Bluml et al., 2012), which are central to the mechanisms of joint inflammation and disease progression (Upadhyay et al., 2009; Pap et al., 2011). In contrast to the a cellular nature of healthy synovial membrane, the synovial membrane of RA patients contains a large cellular infiltrate consisting mainly of macrophages and $\mathrm{T}$ cells, but plasma cells, dendritic cells, neutrophils and activated fibroblasts are also found (Ahern and Brennan, 2011). That can be able to produce matrix metalloproteinases involved in the degradation of cartilage (Vandooren et al., 2009; Laragione et al., 2012).

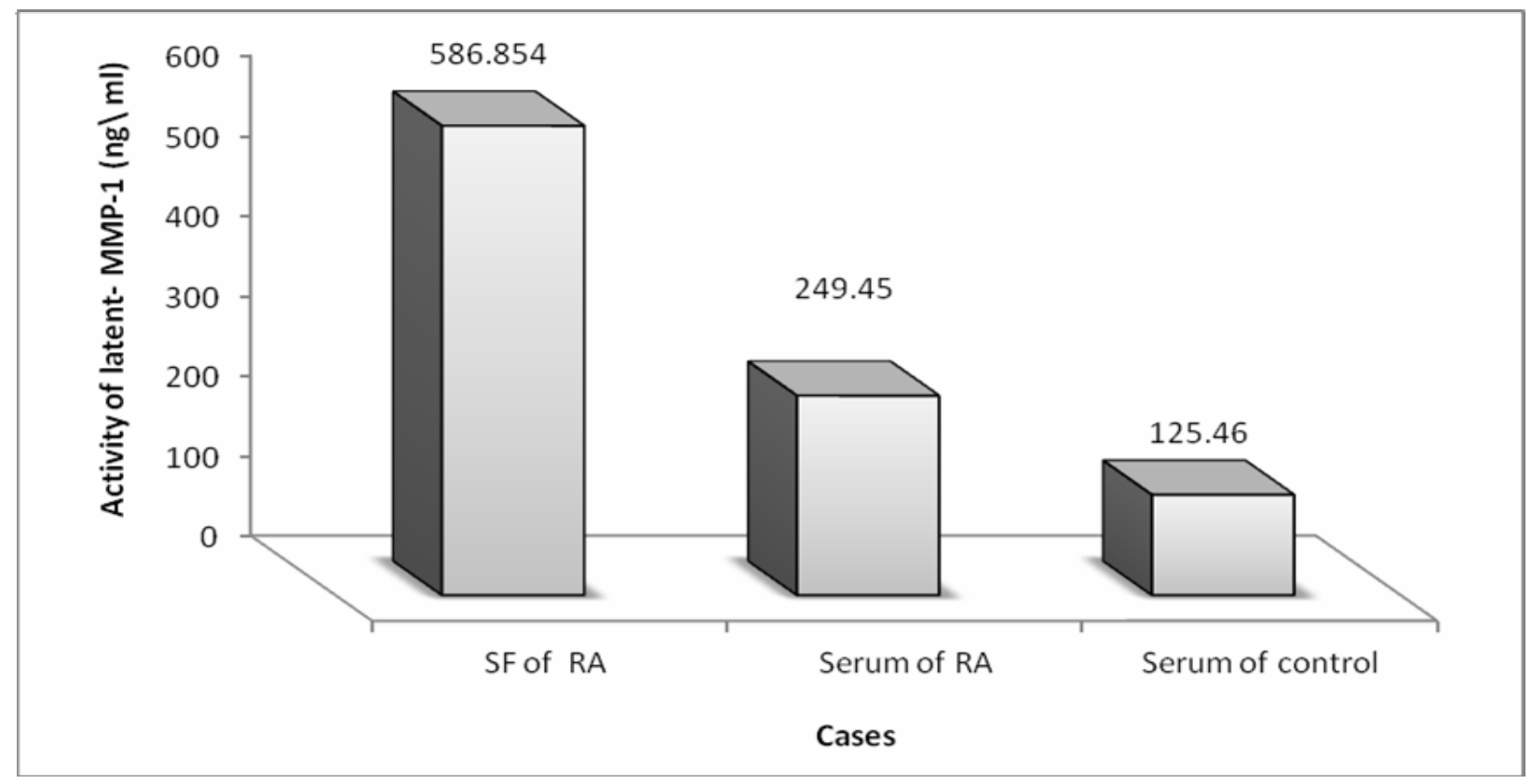

Fig. 1: Latent- MMP-1 activity in SF, serum of patients with RA and serum of control.

Table 1: Latent- MMP-1 activity in SF, serum of patients with RA and serum of control

\begin{tabular}{|c|c|c|}
\hline \multirow{2}{*}{ Source of enzyme } & \multirow{2}{*}{ NO. } & Activity of latent MMP-1 ( ng/ml ) \\
\cline { 3 - 3 } & & Mean \pm SD \\
\hline Synovial Fluid of patients & 30 & $* * * 586.8540 \pm 40.89894$ \\
\hline Serum of patients & 35 & $* * 249.4463 \pm 61.10834$ \\
\hline Serum of control & 60 & $125.4610 \pm 54.87953$ \\
\hline
\end{tabular}

On the other hand, the enzyme level in the serum of control group was lower when compared with the of RA patients serum. This is probably due to the fact that the enzyme in normal human cartilage was bound to an inhibitor named tissue inhibitor of metalloproteinase (TIMP) (Maeda et al., 1995; Sandya et al., 2009). 
Factors such as gender, age, geographical place and smoking and their effects on the enzyme activity were studied. The results showed that gender, age and geographical place, (Table 2, 3 and 4 respectively) had no significant effect on the activity of enzyme in patients and control. On the other hand, (Fig. 2) showed that the activity of enzyme in smoker patients and control was increased significantly at $(p \leq 0.05)$. This can attributed to the presence of nicotine in the cigarettes which causes induced secretion of MMP-1 after smoking of several cigarettes in one day. Those cells exposed to cigarette smoke might produce considerably more of this enzyme than that normally present in non- smokers and up to $40 \%$ less collagen in smokers (Lahmann et al., 2001).

Table 2: Effect of gender on latent- MMP-1 activity in SF, serum of patients with RA and serum of control.

\begin{tabular}{|c|c|c|c|c|}
\hline \multirow{2}{*}{ Source of enzyme } & \multicolumn{3}{|c|}{ Activity of latent MMP-1 (ng/ml ) } \\
\cline { 2 - 5 } & \multicolumn{3}{|c|}{ Mean \pm SD } \\
\cline { 2 - 5 } & Females & No. & Males & No. \\
\hline Synovial fluid of patients & $575.66 \pm 42.46$ & 17 & $601.1 \pm 35.66$ & 13 \\
\hline Serum of patients & $244.98 \pm 58.96$ & 25 & $276.26 \pm 74.11$ & 10 \\
\hline Serum of control & $125.42 \pm 54.43$ & 36 & $125.52 \pm 98.17$ & 24 \\
\hline
\end{tabular}

Table 3: Effect of age on latent- MMP-1 activity in SF, serum of patients with RA and serum of control.

\begin{tabular}{|c|c|c|c|}
\hline \multirow{2}{*}{ Source of enzyme } & \multicolumn{3}{|c|}{ Activity of latent MMP-1 (ng/ml ) } \\
\cline { 2 - 4 } & \multicolumn{3}{|c|}{ Mean \pm SD } \\
\cline { 2 - 4 } & $\begin{array}{c}\text { 39 } \leq \text { years } \\
\text { ( No. })\end{array}$ & $\begin{array}{c}\text { 40-55years } \\
\text { ( No. })\end{array}$ & $\begin{array}{c}\mathbf{5 6} \geq \text { years } \\
\text { ( No. })\end{array}$ \\
\hline \multirow{2}{*}{ Synovial fluid of patients } & $\begin{array}{c}573.19 \pm 43.38 \\
(8)\end{array}$ & $\begin{array}{c}579.44 \pm 3.23 \\
(13)\end{array}$ & $\begin{array}{c}605.59 \pm 52.21 \\
(9)\end{array}$ \\
\hline Serum of patients & $\begin{array}{c}234.43 \pm 51.43 \\
(10)\end{array}$ & $\begin{array}{c}248.4 \pm 51.434 \\
(15)\end{array}$ & $\begin{array}{c}266.17 \pm 82.36 \\
(10)\end{array}$ \\
\hline \multirow{2}{*}{ Serum of control } & $110.99 \pm 46.31$ & $120.77 \pm 62.89$ & $146.59 \pm 56.71$ \\
& $(24)$ & $(16)$ & $(20)$ \\
\hline
\end{tabular}

Table 4: Effect of a geographical place on latent -MMP-1 activity in both SF, serum of patients with RA and serum of control

\begin{tabular}{|c|c|c|c|}
\hline \multirow{2}{*}{$\begin{array}{c}\text { Geographical } \\
\text { place }\end{array}$} & \multicolumn{3}{|c|}{ Activity of latent MMP-1 (ng/ml ) } \\
\cline { 2 - 4 } & \multicolumn{3}{|c|}{ Mean \pm SD } \\
\cline { 2 - 4 } & Synovial fluid of patients & Serum of patients & Serum of control \\
\hline Urban & $601.10 \pm 35.66$ & $276.26 \pm 74.11$ & $127.68 \pm 55.12$ \\
\hline Rural & $575.66 \pm 42.46$ & $244.98 \pm 58.96$ & $105.50 \pm 59.23$ \\
\hline
\end{tabular}




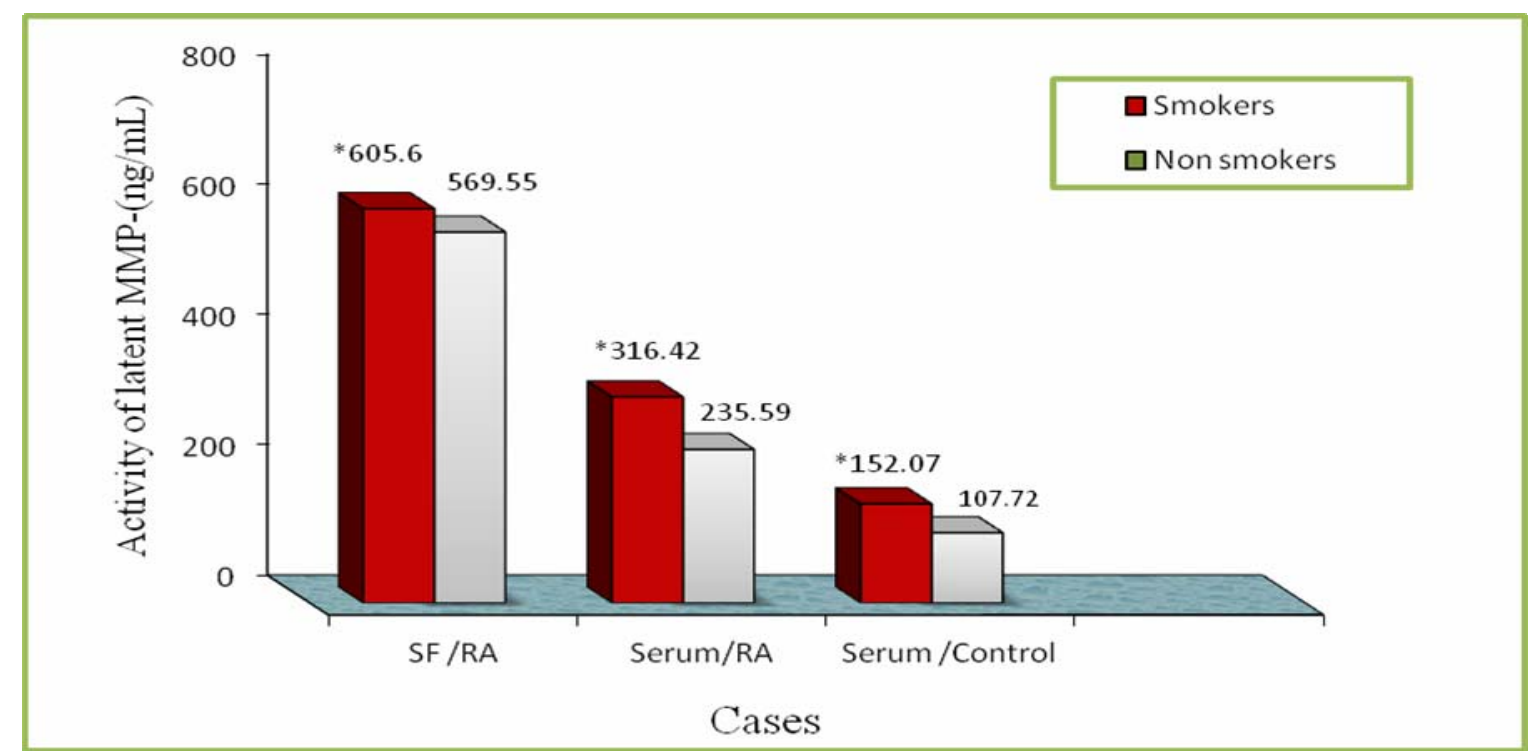

* Significant difference at $(\mathrm{p} \leq 0.05)$.

Fig. 2: Effect of a smoking on latent MMP-1 activity in SF, serum of patients with RA and serum control

(Fig. 3) showed that the percentage prevalence of RA disease in Nineveh Governorate from (158) patients with RA was found to be $83 \%$ and $26 \%$ in females and males respectively. This might be due to the difference in the natural physiology between females and males (Mohan and Priyav, 2010; Tetike et al., 2010; Aryaein et al., 2011) and most patients were at the age between 40 and 50 years (Fig. 4). These results were in a good agreement with a previous study (Mohan and Priyav, 2010).

(Fig. 5) showed that the number of patients living in urban (114) is higher than those living in rural (44). This might can be attributed that urban patients are more exposure to the reactive oxygen species (ROS) which play major role(s) in the generation of acute and chronic inflammatory diseases (Tetike et al., 2010; Aryaein et al., 2011).

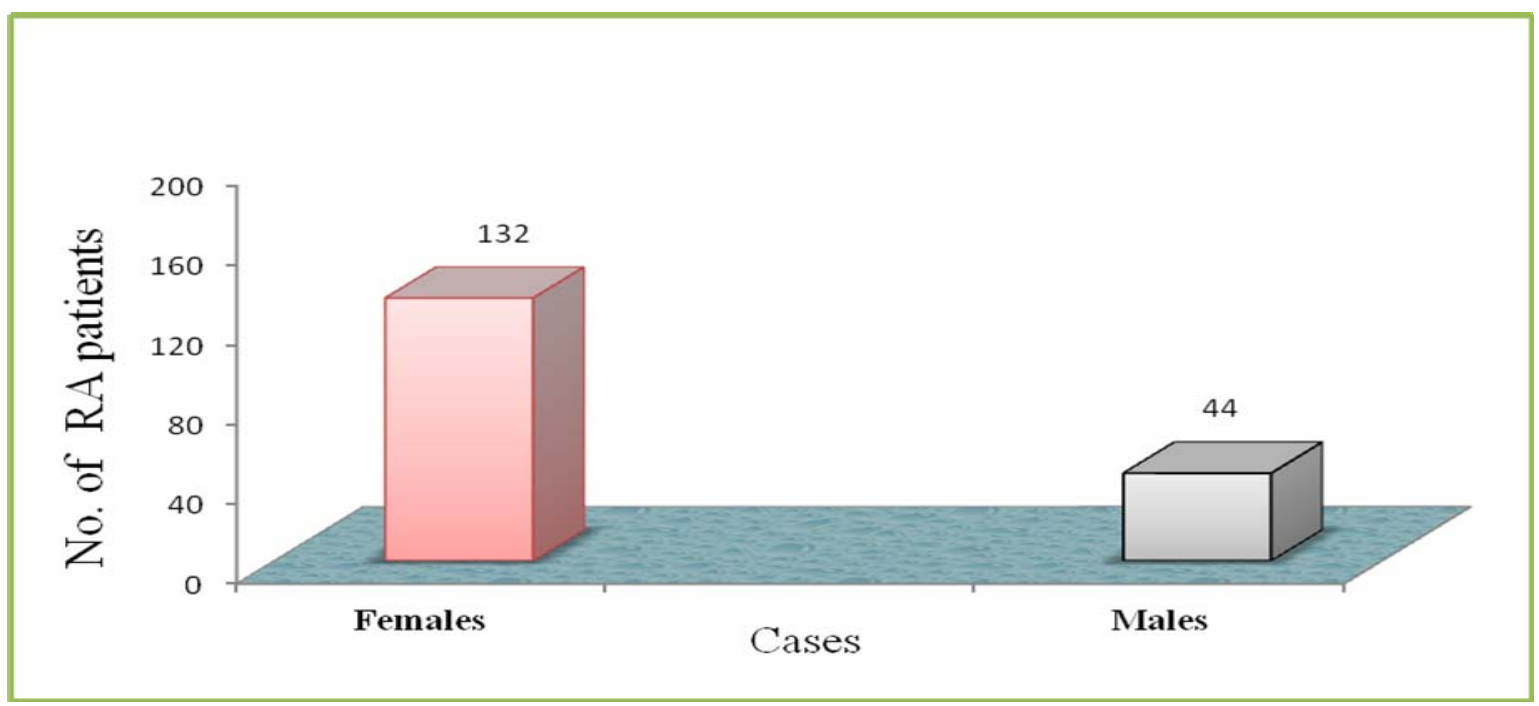

Fig. 3: Number of female and male patients with RA in Nineveh Governorate 


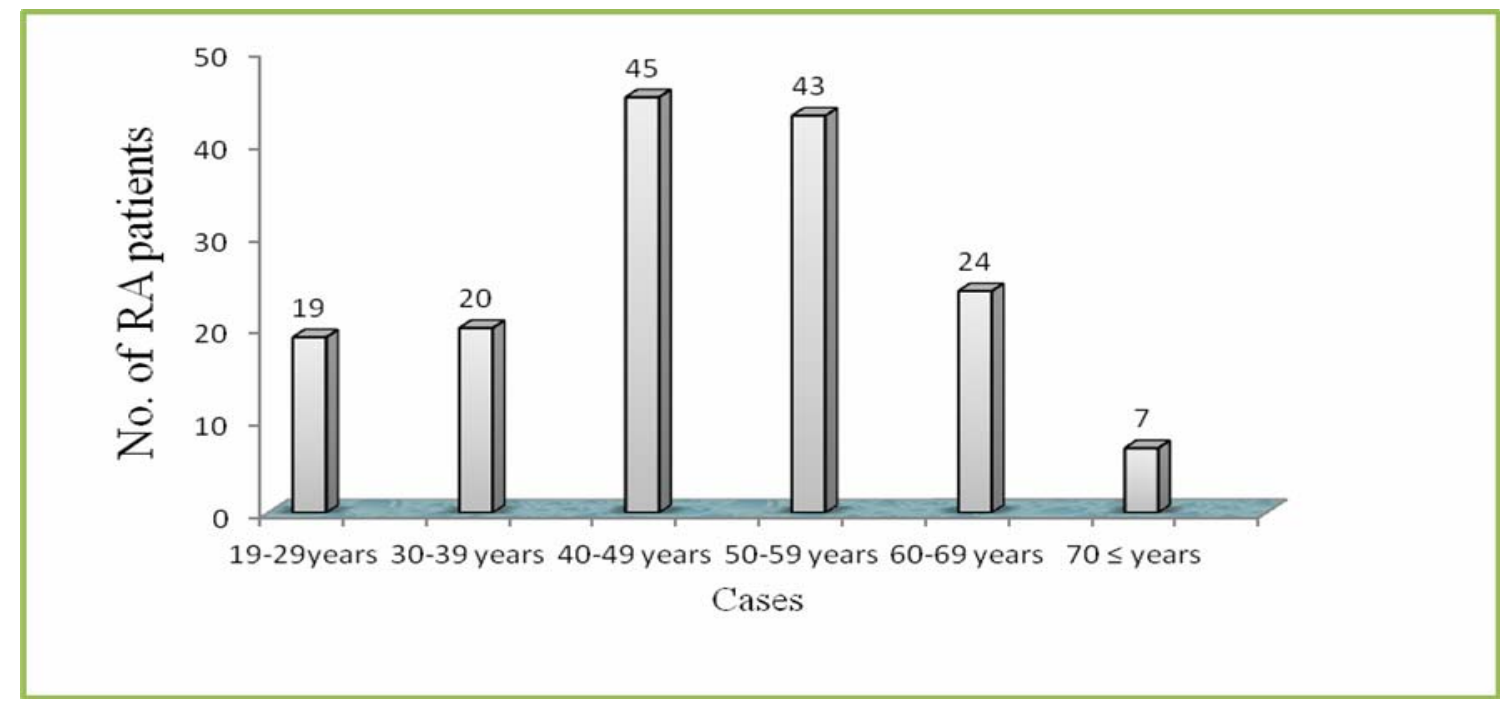

Fig. 4: Number of patients with RA according to age in Nineveh Governorate

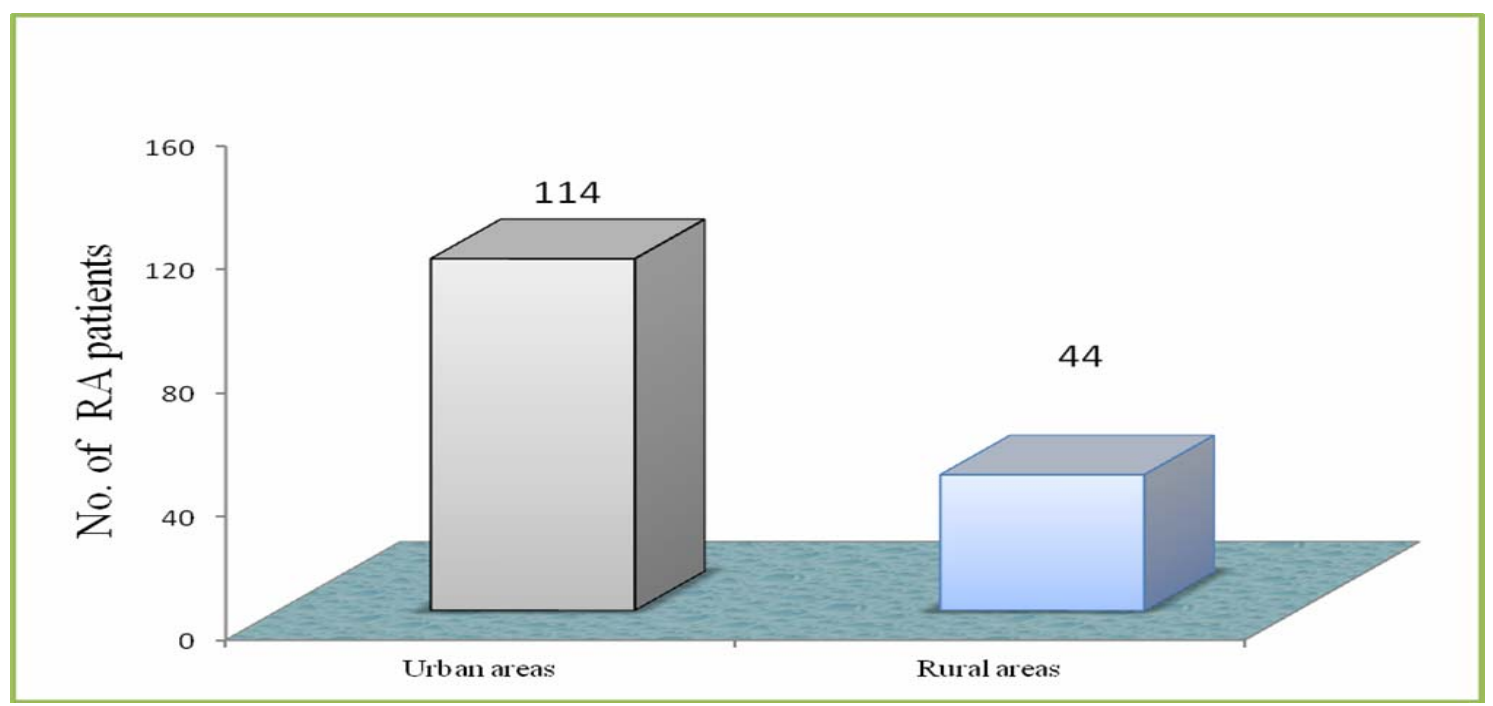

Fig. 5: Number of urban and rural patients with RA in Nineveh Governorat

\section{REFERENCES}

Ahern, D.; Brennan, F. (2011). The role of natural killer cells in the pathogenesis of rheumatoid arthritis: major contributers or essential homeostatic modulators?. Immunology Letters. 136, 115-121.

Alizadeh, H.; Li, H.; Neelam, S.; Niederkorn, J.Y. (2008). Modulation of corneal and stromal matrix metalloproteinase by the mannose-induced Acanthamoeba cytolytic protein. Experimental Eye Research. 87, 286-291.

Aryaeian, N.; Djalali, E.A.; Shahram, F.; Jazayeri Sh.; Camari M.; Nazari, S.A. (2011). Beta_carotene, vitamine, MDA, glutathione reductase and arylesterase activity levels in patients with active rheumatoid arthritis. Iranian J. Publ. Health. 40(2), 102-109. 
Biljana, E.; Boris, V.; Cena, D.; Stefkovska, V. (2011). Matrix metalloproteinases (with accent to collagenases). Cell and Animal Biology. 5(7), 113-120.

Bluml, S.; Scheinecker, C.; Smolen, J.S.; Redlich, K. (2012). Targgting TNF receptors in rheumatoid arthritis. International immunology. (review), 1-7.

Brennan, F.M. and Mclnnes I.B. (2008). Evidence that cytokines play a role in rheumatoid arthritis. J. Clin. Invest. 118, 3537- 3545.

Chen, Y.; Nixon, N.B.; Dawes, P.T.; Mattey, D.L. (2012). Influence of variations across the MMP-1 and -3 genes on the serum levels of MMP-1 and -3 and disease activity in rheumatoid arthritis. Genes Immunity, 13, 29-37.

Daboor, S.M.; Budge, S.M.; Ghaly, A.E.; Brooks M.S.; Dave, D. (2012). Isolation and activation of collagenase from fish processing wast. Advances in Bioscience and Biotechnolofy. 3, 191-203.

Freimanis, G.; Hooley, P.; Ejtehadi, H.D.; Ali, H.A.; Veich, A.; Rylance, P.B.; Alawi, A.; Axford, J.; Nevill, A.; Murray, P.G.; Nelson, P.N. (2010). Arole for human endogenous retrovirus-K (HML-2) in rheumatoid arthritis: investigating mechanisms of pathogenesis. Clin. and Experimental Immunology, 160, 340-347.

Gross, J.; Nagai, W. (1965). Specific degradation of the collagen molecule by tadpole collagenolytic enzyme. J. Biochem. 54,1197-1204.

John, H.; Klippel, M.D.; John H.; Stone; M.D.; M.P.H.; Leslie, J.; Crofford, E. (2008). "Primer on the Rheumatic Diseases". 13th Ed. , 115-140.

Kaar, J.; Li Y.; Blair H.; Asche G.; Koepsel, R.; Huard, J.; Russell, A.(2008). Matrix metalloproteinase-1 treatment of muscle fibrosis. Acta. Biomaterialia. 4, 14111420.

Kim, K.S.; Choi, H.M.; Lee, Y.A.; Choi, I.A.; Lee, S.H.; Hong, S.J.; Yang, H.I.; Yoo, M.C. (2011). Expression of gelatinases MMP-2 and MMP-9 and colagenases MMP-1 and MMP-3 with VEGF in synovial fluid of patients with arthritis. Rheumatol Int., 31, 543-547.

Kirkwood, B.R. (1988). "Essentials of Medical Statistics". 1st edn, Blackwell Scientific Publications, Oxford.

Kokebie, R.; Aggarwal, R.; Lidder, S.; Hakimiyan, A.; Rueger, D.; Block, J. ; Chubinskaya, S. (2011). The role of synovial fluid markers of catabolism and anabolism in osteoarthritis, rheumatoid arthritis and asymptomatic organ donors. Arthritis Research and Therapy. 13, 2-10.

Lahmann, C.; Bergemann, J.; Harrison, G.; Young, A. R. (2001). Matrix metalloproteinase1 and skin aging in smokers. The Lancet, 24, 935-936.

Laragione, T.; Shah, A.; Gulko, P. (2012). The vitamin D receptor regulates rheumatoid arthritis synovial fibroblast invasion and morphology. Laragione E.T. A.L. 18, 194-200.

Maeda, S.; Sawai, T.; Uzuki, M.; Takahashi, Y.; Omoto, H.; Seki, M.; Sakurai, M. (1995). Determination of interstitial collagenase (MMP-1) in patients with rheumatoid arthritis. Annals the Rheumatic Diseases., 54, 970-975.

Matsumoto, T.; Tsurumoto, T.; Shindo, H. ( 2006 ). Interleukin-6 levels in synovial fluids of patients with rheumatoid arthiritis correlated with the infiltration of inflammatory cells in synovial membrane. Rheumatol Int. 26, 1096-1100.

Mohn, S.K.; Priyav, V. (2010). Serum total sialic acid, lipid peroxidation and glutathione reductase levels patients with rheumatoid arhtiritis. Turk Med Sci ., 40(4), 537-540. 
Pap, T.; Meinecke, I.; Ladner, U.M.; Gay, S. (2011). Are fibroblasts involved in joint destruction?. Ann. Rheum. Dis. 64, 52-54.

Peak, N.J.; Khawaja, K.; Myers, A.; Jones, D.; Cawston, T.E.; Rawan, A.D.; Foster, H.E. (2005). Levels of matrix metalloproteinase (MMP-1) in paired sera and synovial fluids of juvinale idiopathic arthiritis patients: relationship to inflammatory activity, MMP-3 and tissue inhibitor of metalloproteinases-1 in alongitudinal study. Rheumatology. 44,1383-1389.

Sandya, S.; Achan, M.A.; Sudhakaran, P.R. (2009). Multiple matrix metalloproteinases in type II collagen induced arthritis. Indian J. of clinical Biochem. 24(1), 42-48.

Schere, S.; Souza, T.; Paoli, J.; Brenol, C.V.; Xavier, R.M.; Chies, J.A.; Simon, D. (2010). Matrix metalloproteinase gene polymorphism in patients with rheumatoid arthritis. Rheumatol Int. 30, 369-373.

Seven, A.; Güzel S.; Aslan, M.; Hamuryudan, V. (2009). Serum and synovial fluid leptin levels and markers of inflammation in rheumatoid arthritis. Rheumatol. Int. 29, 743-747.

Tetike, S.; Ahmad, S.; Alturfan, A.A.; Fresko, I.; Disbudak, M.; Sahin, Y.; Akosy, H.; Yardimci, K.T. (2010). Determination of oxidant stress in plasma of rheumatoid arthiritis and primary osteoarthritis patients. Indian J. Biochem. Biophys. 47,12251233.

Upadhyay, A.; Sharma, G.; Kivivuori, S.; Raye, S.W.; Zabihi, E. (2009). Role of a LIF antagonist in LIF and OSM induced MMP-1, MMP-3, and TIMP-1 expression by primary articular chondrocytes. J. Cytokine .46, 332-338.

Vandooren, V.; Cantaert, T.; Lierop, M.; Bos, E.; Rycke, L.; Veys, E. Keyser, F.; Presnihan, V.; Luyten, F.; Verdonk, P.; Tak, P.; Boots, A.; Baeten, D. (2009). Melanoma inhibitory activity, a biomarker related to chondrocyte anabolism, is reversibly suppressed by proinflammatory cytokines in rheumatoid arthritis. Ann. Rheum. Dis. 68, 1044-1050. 